\title{
Toxic Effect of Fenamiphos on the Earthworm, Eisenia fetida (Annelida: Oligochaeta)
}

\author{
Fenamiphos'un Eisenia fetida (Annelida, Oligochaeta) Üzerine \\ Toksik Etkileri
}

Research Article

Esra Akat*, Sezgi Arman

Ege University, Science Faculty, Biology Department, Zoology Section, Bornova, İzmir, Turkey.

\begin{abstract}
A B S TR ACT
$\mathrm{T}$

- he aim of the present study was to investigate for the first time adverse effect of fenamiphos on the earthworm, Eisenia fetida. Earthworms were exposed to different concentrations of fenamiphos (5, 10 and 20 $\mathrm{mg} / \mathrm{kg}$ ). After $96 \mathrm{~h}$, earthworms were euthanized and fixed. Histological alterations in earthworm's body wall (epidermis, circular and longitudinal muscles), chloragogenous tissue and intestinal epithelium were assessed. Histopathological changes were more prominent in medium (10 mg/kg) and high-concentration (20 mg/ $\mathrm{kg}$ ) groups than in the low-concentration $(5 \mathrm{mg} / \mathrm{kg})$ group. Degeneration in the intestine and integumentary system, as our results indicated after exposure to fenamiphos, are likely to interfere with the correct functioning of the intestine and integumentary system may affect earthworm survival.
\end{abstract}

\section{Key Words}

Fenamiphos, earthworms, intestine, body wall.

\section{ÖZET}

Sunulan bu çalışma, fenamiphosun toprak solucanı Eisenia fetida üzerine olumsuz etkilerini inceleyen ilk çalışmadır. Toprak solucanları fenamiphosun farklı derişimlerine $(5,10$ ve $20 \mathrm{mg} / \mathrm{kg}$ ) maruz bırakıldı. Toprak solucanları 96 saat sonra ötenazi edildi ve solucanların fiksasyonu yapıldı. Toprak solucanlarının vücut duvarlarındaki (epidermis, halkasal ve boyuna kaslar), klorojen hücrelerindeki ve bağırsak epitelindeki histolojik değişiklikler değerlendirildi. Histopatolojik değişiklikler düşük doz (5 mg/kg) uygulama grubuna göre orta (10 $\mathrm{mg} / \mathrm{kg}$ ) ve yüksek doz $(20 \mathrm{mg} / \mathrm{kg})$ uygulama gruplarında daha belirgindi. Fenamiphos maruziyetinden sonra elde ettiğimiz bulgulara göre derideki ve bağırsak sistemindeki dejenerasyon bu iki sistemin fonksiyonunu tam olarak yerine getirememesi sonucu toprak solucanlarının canlılıklarını sürdürmeleri üzerine olumsuz etkiye neden olabilir.

\section{Anahtar Kelimeler}

Fenamiphos, toprak solucanı, bağırsak, vücut duvarı.

Article History: Received: Jun 22, 2015; Revised: Mar 12, 2016; Accepted: Mar 20, 2016; Available Online: Apr 1, 2016.

Dol: 10.15671/HJBC.20164417647

Correspondence to: E. Akat, Ege University, Science Faculty, Biology Department, Zoology Section, Izmir, Turkey. 


\section{INTRODUCTION}

O rganophosphorus pesticides are among the most widely used pesticides in agriculture and public health [1]. Fenamiphos (0-ethyl-O(3methyl-4-methylthiophenyl)-isopropylamidophosphate), an organophosphorus pesticide, is used as nematicide or insecticide and also used on bowling greens and ornamental crops $[2,3]$ Fenamiphos can be quickly oxidized to fenamiphos sulfoxide (FSO), followed by further oxidation to fenamiphos sulfone $\left(\mathrm{FSO}_{2}\right)[4,5]$. Due to the high solubility of fenamiphos in water $(0.4 \mathrm{~g} / \mathrm{L})$ and quick oxidation of it, there is a major concern about nontarget organisms in soil. Additionally, considering the fact that fenamiphos and its degradation products are soluble in water, it is highly likely that these compounds can migrate from the soils to the underlying groundwater $[6,7]$.

Earthworms are particularly important members of soil biota, considered as a biofertilizer, composting agent, moisture retainer crusher and biological agent [8]. These important roles induce significant increases in the yields of several crops, with a prominent reduction in pesticide use and almost zero chemical fertilizer input [9]. Additionally, earthworms are known to accumulate heavy metals, pesticides, and other organic chemicals. Therefore they are considered as a model for assessing the general impact of pollution on the soil [10]. Although the importance of earthworms has been well recognized, there is still a need for further studies on the toxicity of specific pesticides in order to be able to select chemicals that cause little harm to non-target organisms [11]. In previous studies, histopathological alterations in earthworms have been reported as valuable markers of toxicity [12-15]. However, there is no information about histopathological effects of fenamiphos on the earthworms. The aim of the present study was to investigate the histopathological effects of fenamiphos on the earthworm, Eisenia fetida.

\section{MATERIALS AND METHODS}

Earthworms (E. fetida) were collected from Ege University Campus in Izmir, Turkey, in an area that has not been treated with pesticides. We used earthworms of similar size ranging from 85 to 125 $\mathrm{mm}$ in length and 1.20 to $1.40 \mathrm{~g}$ in body weight. The worms were maintained in a soil mixture in the dark at $14 \pm 1^{\circ} \mathrm{C}$ for $48 \mathrm{~h}$ before the experiment. After $48 \mathrm{~h}$, they were randomly divided into either control group or fenamiphos-treated groups each containing ten adult earthworms. $E$. fetida samples were added to contaminated soil of different concentrations along with a control group (distilled water). They were maintained under laboratory conditions in the dark at $14 \pm 1^{\circ} \mathrm{C}$. The targeted amount of fenamiphos applied in the field ranges from 10 to $45 \mathrm{mg} / \mathrm{kg}$ soil which results in the use of $6-10 \mathrm{~kg} / \mathrm{ha}$ under practical conditions depending on the crop $[16,17]$. It was reported that normal field application rates of fenamiphos can vary between 0.5 and $10 \mathrm{~kg} / \mathrm{ha}$, equivalent to 5 and $100 \mathrm{mg} / \mathrm{kg}$ soil $[18,19]$. Based on these data points, fenamiphos concentrations of this study were determined. A stock solution was prepared. A series of three concentrations of fenamiphos $(5 \mathrm{mg} / \mathrm{kg}, 10 \mathrm{mg} / \mathrm{kg}$ and $20 \mathrm{mg} /$ $\mathrm{kg}$ ) were prepared by adding a calculated volume from the stock solution into test containers. After mixing them adequately, soil samples were adjusted to $40-50 \%$ water capacity and 500 g moist soil for each group was transfered into containers. Experimental groups contained low concentration $(5 \mathrm{mg} / \mathrm{kg})$, medium concentration $(10 \mathrm{mg} / \mathrm{kg}$ ) and high concentration ( $20 \mathrm{mg} / \mathrm{kg}$ ). It is believed that these concentrations of fenamiphos are the ones which earthworms could encounter in the environment. Fenamiphos (purity 98\%) was supplied by AgroBest Grup (Izmir, Turkey). After $96 \mathrm{~h}$ exposure to fenamiphos, earthworms were euthanized.

For all experimental groups, earthworms were fixed in Bouin's fluid at $4^{\circ} \mathrm{C}$ for $24 \mathrm{~h}$. Fragments of earthworms were processed according to the standard histological techniques, embedded in paraffin and cut into $5 \mu \mathrm{m}$ transverse sections in the intestinal region, approximately 10 segments behind the clitellum. Thereafter five micrometers serial sections were stained with Gill's hematoxylin-eosin [20] and photographed with using a Leica DM3000 microscope (Leica Microsystems) that was equipped with a Leica digital camera (DFC290). 

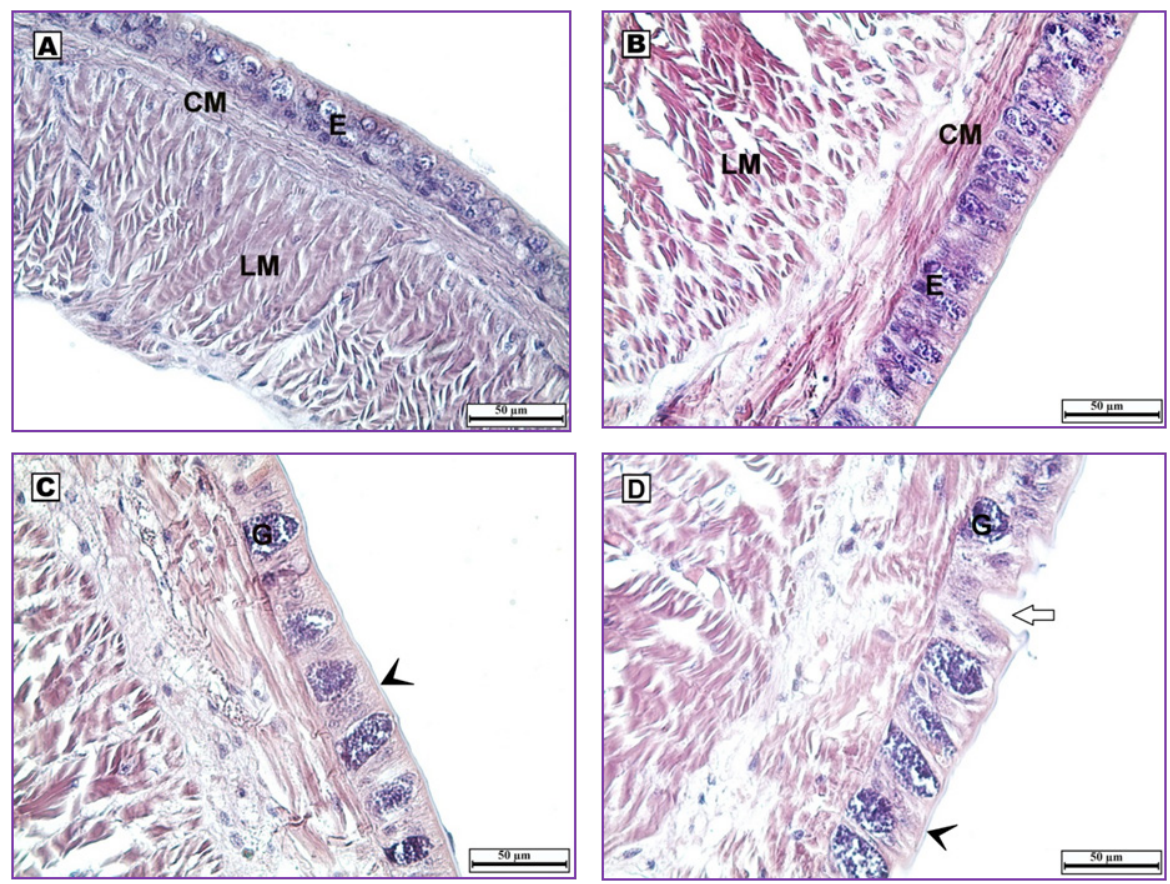

Figure 1. Histopathological alterations in the body wall of E. fetida samples from Turkey A. Control: normal appearance of epidermis (E), circular muscle (CM) and longitudinal muscle (LM) B. Low-concentration group: Moderately increased in glandular cells C. Medium-concentration group: increases in the number of glandular epithelial cells (G) and hypertrophy of these cells with increased mucus production (arrow head) D. High-concentration group: irregular appearance of circular muscles, disintegration of longitudinal muscles, enlargement of epithelial cell line, hyperplasia and hypertrophy of the glandular cells with increased mucus production (arrow head) and disintegration of epidermis (white arrow) (magnification $\mathrm{x} 40)$ Bar $=50 \mu \mathrm{m}$.

\section{RESULTS AND DISCUSSION}

The present study was carried out to determine histopathological changes in the earthworm, E. fetida which was exposed to different fenamiphos concentrations. Light microscopic observations indicated that fenamiphos caused concentration-related in both body wall and intestine deformation such as degeneration in epithelial cell line, irregular appearance of circular muscles, disintegration of Iongitudinal muscles, hyperplasia and hypertrophy of the glandular cells. No mortality was observed during the experiment. Histopathological changes were more clearly seen in the medium (10 mg/ $\mathrm{kg}$ ) and high-concentration $(20 \mathrm{mg} / \mathrm{kg}$ ) groups than in the low-concentration $(5 \mathrm{mg} / \mathrm{kg}$ ) group.

Body wall in control group, the appearance of epidermis with glandular cells, and circular and longitudinal muscle layers were normal (Figure 1A). In low-concentration group, a moderately increased number of glandular cells (Figure 1B).
In both medium and high-concentration groups increases in mucus production and the number of glandular epithelial cells, and also hypersecretion in glandular cells were observed (Figures $1 C$ and 1D). This may be an early result of contact with pollutants, which are known to cause excessive epidermal mucus secretion [21,22]. The effects of soil pollution along Porsuk River Basin on the bioindicator organism Lumbricus terrestris was investigated and the author determined hyperplasia of glandular cells, increasing in mucus production, deformation of circular and longitudinal muscles [14]. Additionally, the effects of sublethal concentrations of benzene, toluene and xylene on Eudrilus eugeniae were studied and observed similar histopathological changes [23]. These histopathological alterations were in accordance with our results.

High-concentration group animals showed an extreme histopathology characterized by irregular appearance of circular muscles, disintegration of longitudinal muscles, enlargement of epithelial cell 

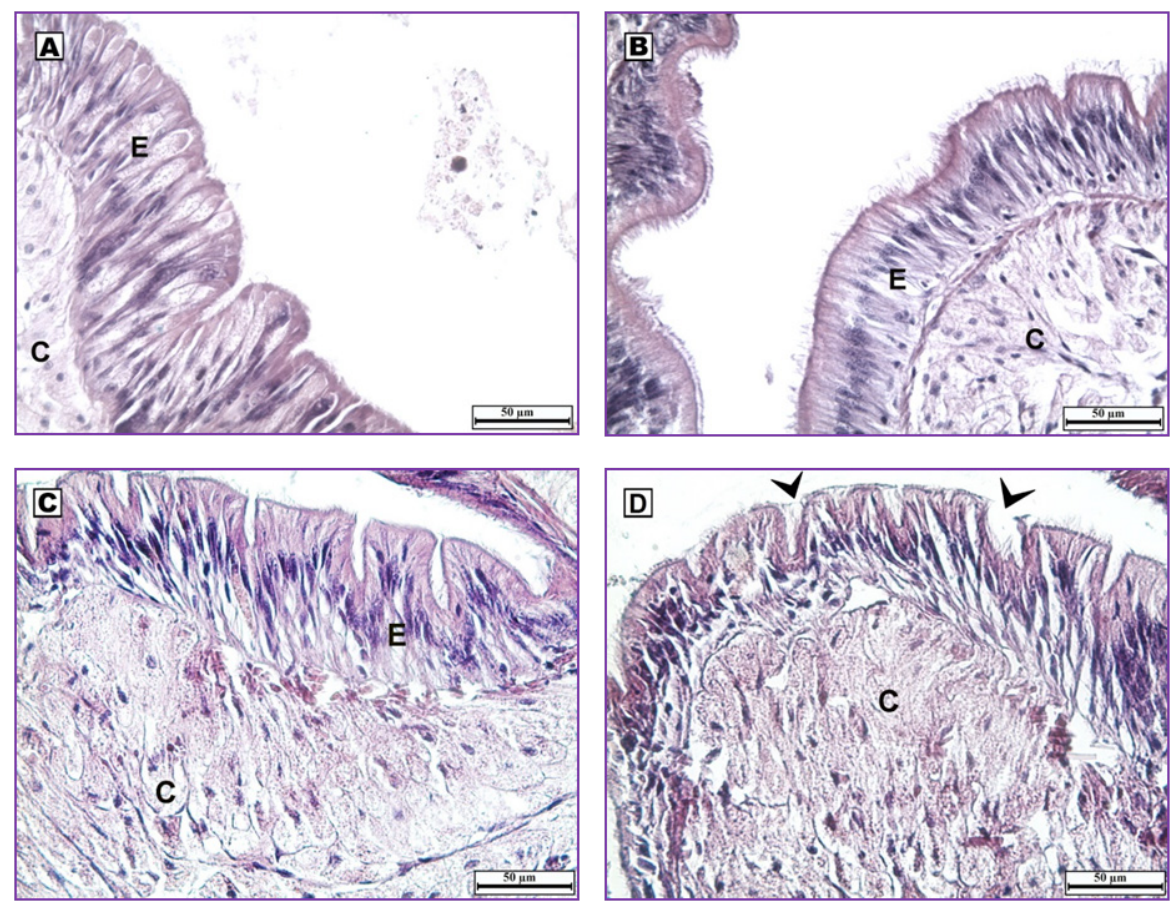

Figure 2. Histopathological alterations in the intestine of E. fetida samples from Turkey A. Control: normal appearance of epithelial cells (E) and chloragogenous cells (C) B. Low-concentration group: weak deformation in both chloragogenous (C) and epithelial cells (E) C. Medium-concentration group: degeneration in both chloragogenous (C) and epithelial cells (E) D. High-concentration group: grossly damaged epithelial (arrow head) and chloragogenous cells (C) (magnification x40) $\mathrm{Bar}=50 \mu \mathrm{m}$.

line with disintegration of epidermis, hyperplasia and hypertrophy of the glandular cells and an increasing in mucus production (Figure 1D). The effects of silver nanoparticles on the $L$. terrestris were evaluated and authors detected potential damages on the integumentary system by silver nanoparticles, could have severe consequences on its integrity as an external barrier [24]. Additionally, it was reported that the cuticle is a primary barrier against both external mechanical, chemical or biological hazards and detriments [24]. Therefore, potential damages on the integumentary system by toxic substances such as fenamiphos, could have severe consequences on its functionality as an external barrier.

The external part of the intestine is covered by the chloragogenous tissue which resemble the liver in vertebrates in terms of function, particularly regarding excretion [25]. Additionally this tissue is able to sequester metals and bind xenobiotics (such as pesticides) $[26,27]$. In control group, the intestine of earthworm consisted of normal epithelial cells (Figure 2A). Slight deformation of chloragogenous and epithelial cells were first observed at low- concentration (Figure 2B). In medium and high-concentration groups, epithelial cell line degeneration were determined and chloragogenous cells were dilated and fused (Figures $2 \mathrm{C}$ and 2D). In highconcentration group, epithelial cells of intestine were grossly destroyed and fused (Figure 2D). Histopathological alterations of the earthworm (L. terrestris) as biomarker of soil pollution along Porsuk River Basin (Turkey) were reported and similar histopathological changes were indicated intestine [14]. The histopathological changes in earthworms (Eisenia andrei) exposed to soil contaminated with uranium mining wastes containing high levels of metals and radionuclides were examined, and authors detected loss of structural integrity in the epidermis, deformation of the circular and longitudinal muscles in body wall, deformation of the chloragogenous tissue reduction of the thickness of the intestinal epithelium [15]. Degeneration in the intestine, as we have indicated can occur after exposure to fenamiphos, is likely to interfere with the correct functioning of the intestine and may affect earthworm survival. 
Consequently, it is widely accepted that the measurement of the biological effects of pollutants has become very important for the environmental risk assessment. Results of the current study represent the effect of fenamiphos on the earthworm, E. fetida which is a sensitive indicator of environmental pollution. Therefore, environmental exposure to fenamiphos may present a significant risk for this species and other soil organisms.

\section{ACKNOWLEDGEMENTS}

The authors thank Eda Gökalp (AgroBest Grup Ltd.) for supplying fenamiphos.

\section{References}

1. E. Hodgson, A text book of modern toxicology. Third edition A John Wiley \& Sons Inc. Publication, (2004).

2. M.A. Kamrin, Pesticide Profiles: Toxicity, Environmental Impact and Fate, CRC Press, LLC, Boca Raton, (1997).

3. T. Kiely, Organophosphate pesticide information: quantitative usage analysis for fenamiphos. U.S. Environmental Protection Agency, (1999). (available at: http://www.epa.gov/oppsrrd1/op/fenamiphos/ fenause.htm)

4. J.B. Kotcon, M. Wimmer, Monitoring movement of fenamiphos through soil water in peach orchards using quantitation by gas chromatography/mass spectrometry, Bull. Environ. Contam. Toxicol., 50 (1993) 35.

5. L.T. Ou, J.E. Thomas, D.W. Dickson, Degradation of fenamiphos in soil with a history of continuous fenamiphos applications, Soil Sci. Soc. Am. J., 58 (1994) 1139.

6. R. Kookana, C. Phang, A.G. Aylmore, Transformation and degradation of fenamiphos nematicide and its metabolites in soils, Aust J Soil Res., 35 (1997) 753.

7. T. Cáceres, M. Mallavarapu, R. Naidu, Degradation of fenamiphos in soil collected from different geographical regions: The influence of soil properties and climatic conditions, J Environ Sci Heal B, 43 (2008) 314.

8. S. Eguchi, R. Hatano, T. Sakuma, Toshio effect of earthworms on the decomposition of soil organic matter, Nippon Dojo-Hiryogaku Zasshi, 66 (1995) 165.

9. M.C. Dash, B.K. Senapathi, National Seminar on Organic Waste Utilize, Vermi Comp Part-13, Proceedings, 157-177 (1986).

10. C.A. Callahan, Earthworms as ecotoxicological assessment tools, United States Environmental Protection Agency EPA-600/D-48-272 (1984).

11. Y.Y. Mosleh, S. Paris-Palacios, M. Couderchet, G. Vernet, Effect of the herbicide isoproturon on survival, growth rate, and protein content of mature earthworms (Lumbricus terrestris L.) and its fate in the soil, Appl. Soil. Ecol., 23 (2003) 69.
12. A. Amaral, M. Soto, R. Cunha, I. Marigómez, A. Rodrigues, Bioavailability and cellular effects of metals on Eisenia fetida inhabiting volcanic soils, Environ. Pollut., 142 (2006) 103.

13. A. Giovanetti, S.Fesenko, M.L. Cozzella, L.D. Asencio, U. Sansone, Bioaccumulation and biological effects in the earthworm Eisenia fetida exposed to natural and depleted uranium, J. Environ. Radioact., 101 (2010) 509.

14. G.A. Kılıç, Histopathological and biochemical alterations of the earthworm (Lumbricus terrestris) as biomarker of soil pollution along Porsuk River Basin (Turkey), Chemosphere, 83 (2011) 1175.

15. J. Lourenço, A. Silva, F. Carvalho, J. Oliveira, M. Malta, S. Mendo, F. Gonçalves, R. Pereira, Histopathological changes in the earthworm Eisenia andrei associated with the exposure to metals and radionuclides, Chemosphere, 85 (2011) 1630.

16. L.T. Ou, P.S.C. Rao, Degradation and metabolism of oxamyl and phenamiphos in soils, J. Environ. Sci. Heal. B., 21 (1986) 25.

17. J.A. Cabrera, A. Kurtz, R.A. Sikora, A. Schouten, Isolation and characterization of fenamiphos degrading bacteria, Biodegradation, 21 (2010) 1017.

18. M. Megharaj, K. Venkateswarlu, A.S. Rao, Effect of monocrotophos and quinalphos on soil algae, Environ. Pollut., 40 (1986) 121.

19. M. Megharaj, I. Singleton, R. Kookanab, R. Naidu, Persistence and effects of fenamiphos on native algal populations and enzymatic activities in soil, Soil Biol. Biochem., 31 (1999) 1549.

20. G.W. Gill, J.K. Frost, K.A. Miller, A new formula for a half-oxidized hematoxylin solution that neither overstains nor requires differentiation, Acta. Cytol., 18 (1974) 300.

21. J.V.Rao, Y.S. Pavan, S.S. Madhavendra, Toxic effects of chlorpyrifos on morphology and acetylcholinesterase activity in the earthworm, Eisenia foetida, Ecotoxicol. Environ. Saf., 54 (2003) 296.

22. X. Pan, W. Song, D. Zhang, Earthworms (Eisenia foetida, Savigny) mucus as complexing ligand for imidacloprid, Biol. Fertil. Soils, 46 (2010) 845.

23. F.J. Eseigbe, V.F. Doherty, T.O. Sogbanmu, A.A. Otitoloju, Histopathology alterations and lipid peroxidation as biomarkers of hydrocarbon-induced stress in earthworm, Eudrilus eugeniae, Environ. Monit. Assess., 185 (2013) 2189.

24. E. Lapied, E. Moudilou, J.M. Exbrayat, D.E. Oughton, E.J. Joner, Silver nanoparticle exposure cause apoptotic response in the earthworm Lumbricus terrestris (Oligochaeta), Nanomedicine, 5 (2010) 975.

25. B.I. Roots, Some observations on the chloragogenous tissue of earthworms, Comp. Biochem. Physiol. Toxicol. Pharmacol., 1 (1960) 218.

26. M.P. Ireland, E. Fisher, Effect of $\mathrm{Pb}^{2+}$ on $\mathrm{Fe}^{3+}$ tissue concentrations and delta-aminolaevulinic acid dehydratase activity in Lumbricus terrestris, Acta. Biol. Acad. Scient. Hung., 29 (1978) 395.

27. K.S. Richards, M.P. Ireland, Glycogen-lead relationship in the earthworm Dendrobaena rubida from a heavy metal site, Histochemistry, 56 (1978) 55. 
